\title{
A IMAGEM DA CAPA
}

írculos, não exatamente concêntricos, eram a imagem do simpósio internacio-
nal que deu origem ao dossiê deste número 12 da Diálogo com a Economia
Criativa. A imagem nos remete a ondas de comunicação. Não necessariamente às ondas de transmissão - no sentido da física -, mas ao efeito multiplicador, propagador, da comunicação. Tal como a onda gerada por uma pedra atirada na água - justamente um círculo -, que gera um efeito de mais outras ondas - outros círculos - em cadeia. A imagem do evento nos fez vislumbrar ainda um túnel da memória... E assim, os círculos foram também o mote da composição gráfica dessa capa.

As capas da Diálogo têm sido criadas por professores da ESPM-Rio, designers, fotógrafos, ilustradores, artistas. Como essa designer é professora de História do Design e de Estética, as referências históricas germinam facilmente. Brincar com círculos nos remeteu, então, às composições daquele que foi o pai do abstracionismo - Wassily Kandinsky. "Círculos em um Círculo", quase integralmente reproduzido nessa capa, é de 1923.

O artista russo foi também professor e teórico, autor de Ponto e linha sobre $o$ plano, opúsculo que analisa os elementos fundamentais da forma. Para ele, a curva seria uma linha reta desviada do seu trajeto por uma pressão lateral continua; e o círculo, a síntese das grandes oposições, a combinação perfeita e equilibrada entre o concêntrico e o excêntrico. Das três formas primárias, o círculo seria a que se direciona claramente para a quarta dimensão.

Por fim, considerando a temática do outro conjunto de textos dessa revista (a visualização da informação), intencionalmente exageramos a superposição de círculos que, inclusive, interferem na imagem de Kandinsky. O propósito era representar o big data visual, a efervescência de imagens que são geradas em grande escala, em novas e novas mídias. Aparece ainda na composição um detalhe de uma antiga gravura de um olho, fazendo referência ao tema. Não à toa, o globo ocular, a pupila, a íris, a córnea são formas circulares. De sua forma fechada, o círculo se expande e se propaga, abrindo novos caminhos, novas possibilidades, novos saberes.

\section{Isabella Perrotta}

